УДК 316.485.6:005.91:656.073.28:005.932

DOI: $10.15673 /$ fie.v12i4.1908

Козак К.Б.

кандидат економічних наук, доцент кафедра менеджменту та логістики E-mail: kozakkate.coach@gmail.com ORCID ID: 0000-0002-8099-6607
Дроздова В.А.

кандидат економічних наук, доцент кафедра менеджменту та логістики

E-mail: 78banka78@gmail.com

ORCID ID: 0000-0003-3143-1869

\author{
Дроздова Є.A. \\ магістрант \\ кафедра менеджменту та логістики \\ Одеська національна академія харчових технологій \\ вул. Канатна 112, м. Одеса, Україна, 65039 \\ E-mail: e.drozdova@gmail.com \\ ORCID ID: 0000-0002-0743-2370
}

\title{
ПОДОЛАННЯ КОНФЛІКТНИХ СИТУАЦІЙ ПРИ АДМІНІСТРУВАННІ ТРАНСПОРТНИХ ПЕРЕВЕЗЕНЬ У ЛОГІСТИЧНИХ СИСТЕМАХ
}

Метою статті $є$ проведення аналізу причин конфліктних ситуацій та конфліктів, що виникають у зв'язку зі складнощами адміністрування (управління) при транспортних перевезеннях, аналізу думок експертів-практиків та вчених щодо подолання подібних складних ситуацій. Оскільки під час управління логістичними процесами у посадових осіб є чітко регламентовані функції, за якими вони повинні фрокусуватися саме на процедурах та контролю за їх виконанням, що іноді стає причинами виникнення конфліктних ситуацій та конфліктів. Завданням статті $€$ встановлення найбільш типових причин конфліктних ситуацій в процесі адміністрування транспортних перевезень; встановлення між якими учасниками логістичної системи найбільш часто виникають конфрліктні ситуації; які існують шляхи та інструменти визначення, згладжування і вирішення подібних складних ситуацій. Розглядаються тенденції розвитку логістичного менеджменту і логістики; поняття логістичної системи, конфліктної ситуації/конфлікту та адміністрування. Аналізуються думки провідних фрахівців ланцюга поставок Українського ринку. Необхідно підкреслити, що конфлікти які виникають при транспортних перевезеннях призводять до значних економічних та іміджевих збитків для підприємства та компаній-партнерів, особливо при здійсненні міжнародних перевезень, а також залишаються поза уваги науковців хоча турбують представників бізнес-структур. Тому саме проблема якісного адміністрування транспортних перевезень у логістичних системах і своєчасне виявлення та подолання конфліктів набуває актуальності.

Ключові слова: конфліктна ситуація, конфлікт, логістична система, транспортні перевезення, логістичне адміністрування, міжнародна логістика.

This work is licensed under a Creative Commons Attribution 4.0 International License http://creativecommons.org/licenses/by/4.0/

Постановка проблеми та зв'язок з важливими науковими та практичними завданнями. Сучасний рівень розвитку логістичного менеджменту спрямовано на ефективне управління логістичними системами, тобто їх адміністрування. 3 усіх видів логістики, саме в рамках транспортної логістики виникає найбільша кількість конфліктних ситуацій, що часто призводять до штрафних санкцій та іміджевих втрат підприємств незалежно від того у якій галузі вони працюють.

Аналіз останніх публікацій по проблемі. На сучасному етапі, одним з ключових понять у логістиці є поняття логістичної системи. У зв'язку з великою кількістю різних методологічних підходів, зарубіжні та вітчизняні науковці не мають чіткого визначення поняття що таке логістична система.

Логістична система - це головний елемент логістики, завдяки який реалізується системний під- хід щодо стабільного функціонування підприємства у сучасних ринкових відносинах. У вітчизняних авторів, найбільш поширеним визначенням поняття логістичної системи, є твердження, що це адаптивна система із зворотнім зв'язком, яка виконує логістичні операції та функції, складається 3 певних підсистем та має розвинені зв'язки з зовнішнім середовищем [2, c. 120]. Зарубіжні вчені та менеджери в області логістики, таки як Д. Клосс, Д. Бауэрсокс [16, с. 467] більш прагматично підходять до визначення поняття «логістичної системи», згідно зі словником APICS: «логістична система - це процес планування та координації всіх аспектів фізичного руху матеріалів, компонентів та готової продукції для мінімізації загальних витрат та забезпечення бажаного рівня сервісу». I це визначення дуже нагадує загальне визначення поняття логістики [3, с. 45].

Наприклад, Лемеш I.О. вважає що логістична 
система - це структурована, складна організаційноекономічна система, яка складається з взаємозалежних елементів, розташованих в єдиному процесі управління потоками (матеріальними, інформаційними, фінансовими потоками), метою функціонування якої $\epsilon$ досягнення поставлених перед логістичною системою цілей і адаптація до ендогенних та екзогенних впливів шляхом оптимізації потокових процесів [5, c. 96].

Аналіз публікацій дозволяє зробити висновок, що дослідженням теоретичних питань логістики та логістичних систем займаються досить багато науковців, натомість деякі практичні питання, такі як конфліктні ситуації, що виникають при транспортуванні та взаємодії транспортних підрозділів з іншими підрозділами всередині фірми та із зовнішніми контрагентами залишаються поза уваги науковців хоча турбують представників бізнес-структур. Так, генеральний директор Національної служби доставки «ІнТайм» (Запоріжжя) Троян А., вважає, що в більшості випадків гарантом подолання конфліктних ситуацій при адмініструванні транспортних перевезень у логістичної системі є вчасний та повноцінний інформаційний обмін між учасниками процесу $[1$, c. 10].

A, Дробин Д., PR-директора «Міст Експрес»
(Київ) визначає: «Постійний діалог та як можна більше зворотного зв'язку, систематизація конфліктів та розстановка пріоритетів; постійна аналітика; розвинута корпоративна культура як загальноприйнята на підприємстві модель поведінки співробітників в поширених ситуаціях - гармонійне співіснування цих інструментів на системній основі дозволяє творити чудеса» [1, с. 9].

Формулювання цілей дослідження. Основною ціллю статті є проведення досліджень, які спрямовані на визначення причин щодо виникнення конфліктів та конфліктних ситуацій, а також дослідження підходів різних провідних фахівців щодо їх подолання при адмініструванні транспортних перевезень у логістичних системах.

Виклад основних результатів та їх обгрунтування. Логістична система складається 3 певних підсистем (функціональних або структурних підрозділів підприємства), які виконують логістичні функції та мають розвинені зв'язки із зовнішнім середовищем (постачальниками, споживачами, партнерами, посередниками), яке об'єднане в єдине логістичне адміністрування для реалізації корпоративної стратегії бізнесу. Логістична система та іiі основні підсистеми представлені на рис.1.

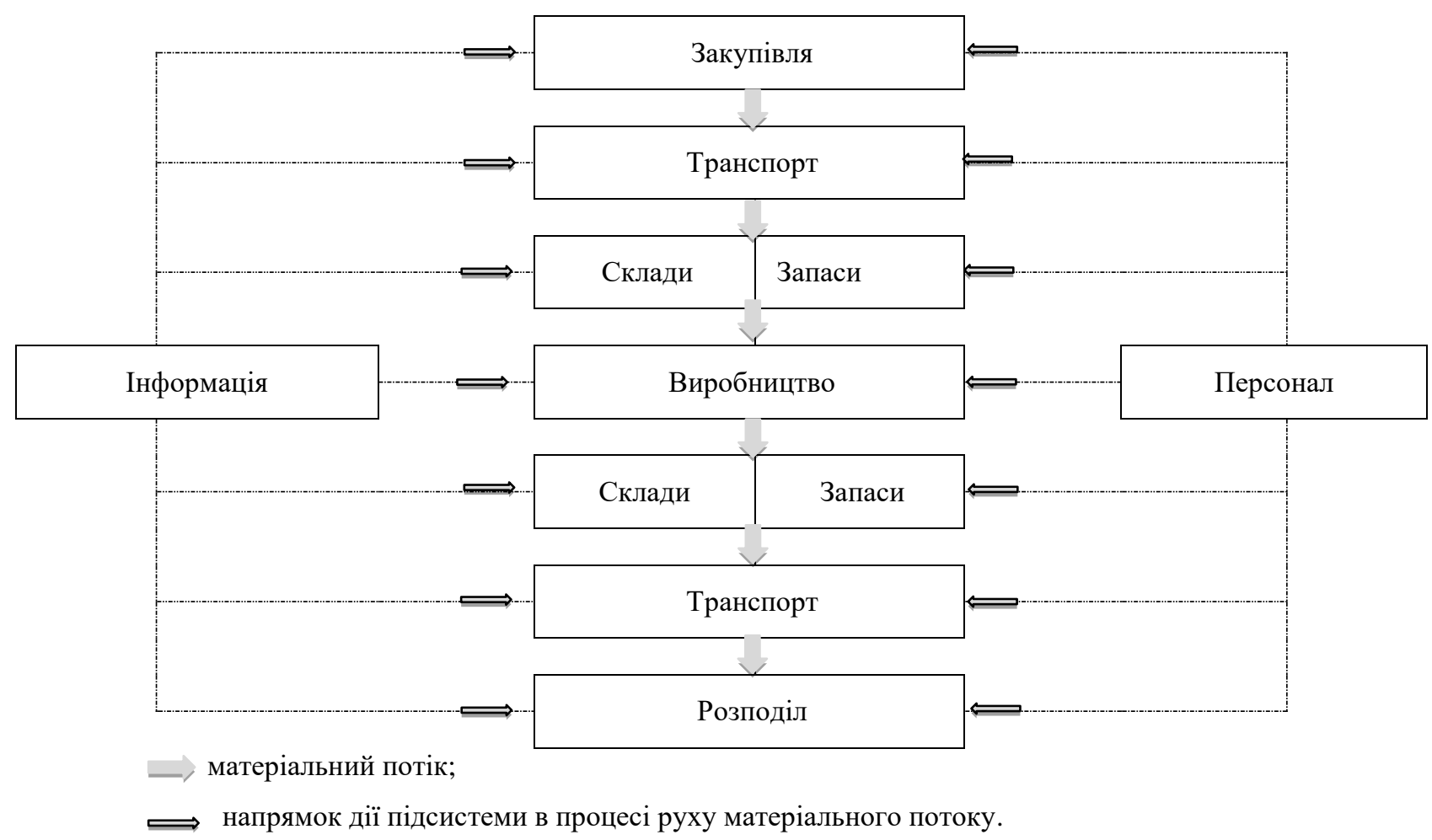

Рис. 1. Комбінації підсистем у класичній логістичній системі*

* опрацьовано за даними [6, с. 134]

Сучасні тенденції розвитку логістичного менеджменту та логістики в цілому, спрямовані на ефективне управління логістичними функціями та функціональними областями. Сукупність цих тенденцій призвело до виникнення поняття «адміністрування логістичної системи» або «логістичне адмініструван- ня» що відноситься до поняття адміністративного менеджменту [4].

Значну роль у виникненні цього поняття, зіграло те, що управління логістичними функціями, операціями та функціональними областями підприємства та його партнерів виконується на базі 
інформаційних технологій та певного комплексу технічних джерел. Отже, завдання логістичного адміністрування - це відомі нам функції адміністративного менеджменту, які традиційно складають комплекс функціональних зобов'язань менеджерів будь-якого підприємства, а саме: планування, організація, аналіз, контролінг, облік та ін. Тому адміністрування логістичної системи або логістичне адміністрування в рамках адміністративного менеджменту можна визначити, як певний комплекс управлінських функцій та процедур які виконуються менеджерами логістики 3 використанням інформаційно-комп'ютерних технологій для досягнення цілей логістичної системи (тактичних, стратегічних, оперативних) [7, с.808].

Важливо зазначити, що організаційна структура менеджменту на підприємствах складається 3 окремих функціональних підрозділів (логістики, виробництва, продаж, маркетингу, фінансів), які мають свої цілі та завдання, а також повинні мати систему оцінювання досягнених результатів згідно з існуючими положеннями на підприємстві. Відмінність інтересів між структурними підрозділами підприємства призводить до виникнення конфліктних ситуацій. Так, для керівництва підприємства, буває непосильним завданням визначити причину різного рівня конфліктів або навіть взагалі зрозуміти, що конфлікт на підприємстві існує і призводить до зниження результативності та ефективності всього бізнесу. Встановлення причини конфліктної ситуації, дозволить розробити ефективні заходи, щодо недопущення виникнення аналогічних ситуацій в подальшому.
Конфліктна ситуація, перш за все, це умови щодо виникнення конфлікту. Конфлікт в психології визначається як відсутність згоди між двома й більше сторонами - особами або групами, та обов'язково наявність певних дій. Якщо розглядати саме конфлікт в рамках підприємства - $є$ ситуації, які виникають в результаті блокування або неузгодженості цілеспрямованої поведінки однієї групи до іншої [8, с.6]. На думку Дробина Д. - конфліктні ситуації або так звані вузькі місця - це постійна складова будь якого процесу бізнесу. Вирішення внутрішніх конфліктів - це робота над стійкістю бізнесу. Пошук зовнішніх конфліктів - це робота з розвитку бізнесу. У транспортних перевезеннях конфліктні ситуації підживлюються невідповідністю можливостей та запитів [1, с.8].

Так, в межах логістичної системи, транспортна підсистема - замикає на себе функціонування всієї товаропровідної системи - та є зв'язуючою ланкою між споживачем, транспортом, постачальником та виробником, забезпечуючи при цьому безперервність та своєчасність іï функціонування. До сукупності загальних функцій адміністрування транспортних перевезень у логістичній системі входять: планування (тактичне, стратегічне, оперативне); організація; прийняття рішень (регулювання); координація (міжфункціональна та міжорганізаційна); аналіз; аудит (внутрішній та зовнішній); контролінг; ціноутворення.

Конфліктні ситуації і навіть конфлікти при адмініструванні транспортних перевезень у логістичних системах можуть виникати на двох рівнях, таких як на міжфункціональний та міжорганізаційний рівні, що наведено на рис.2 [9].

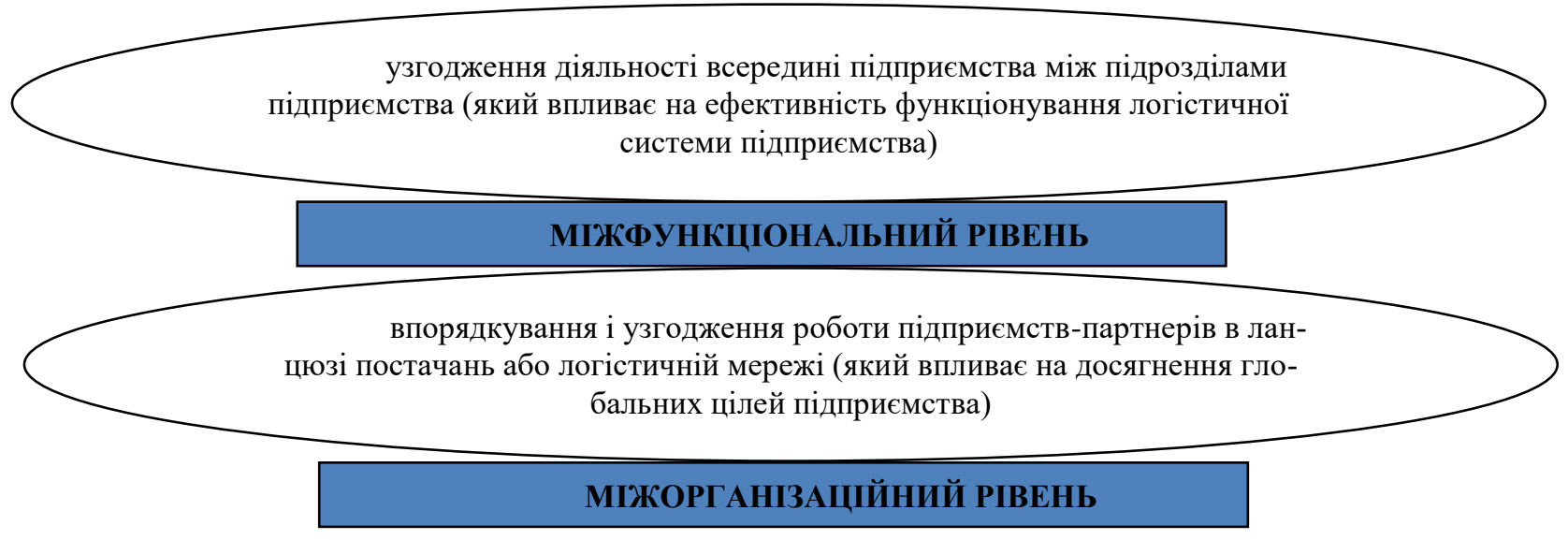

\section{Рис. 2. Рівні виникнення конфліктних ситуацій при адмініструванні транспортних перевезень у логістичних системах* *систематизовано авторами на підставі [9]}

На думку Савчук B. PR-менеджера MEX Advertising (Київ) - частіше виникають конфлікти всередині підприємства між різними структурними підрозділами підприємства, вони можуть мати абсолютно різні причини. Наприклад: недостатність або перекручення передачі інформації, обмежені ресурси, нераціональна організація праці $[1$, с.9].
Подолання конфліктних ситуацій залежить від їх специфіки, причин виникнення та потенційних наслідків. Конфліктні ситуації при адмініструванні транспортних перевезень у логістичній системі і шляхи їх вирішення полягають в наступному (табл.1) 
Таблиця 1

Визначення типових конфліктних ситуацій при адмініструванні транспортних перевезень у логістичній системі*

\begin{tabular}{|c|c|c|}
\hline $\begin{array}{l}\text { № } \\
\text { 3/ח }\end{array}$ & $\begin{array}{c}\text { Рамки / зміст } \\
\text { конфліктної ситуації }\end{array}$ & Стисла характеристика конфліктної ситуації та методи вирішення \\
\hline 1 & $\begin{array}{l}\text { На етапі між } \\
\text { виробництвом та складом }\end{array}$ & $\begin{array}{l}\text { Типовий конфлікт при адмініструванні транспортних перевезень частко- } \\
\text { во виникає ще на етапі між виробництвом та складом, коли здійснюється } \\
\text { завантаження/відправка, а документи на зборку/завантаження зробити не } \\
\text { можливо, тому що в обліковій системі немає товару. Товар при цьому } \\
\text { вже є в наявності, але виробництво партії ще триває. За таких умов треба } \\
\text { очікувати, що несвоєчасне внесення даних виробництва може призвести } \\
\text { до простою транспорту та зниження рівня сервісу доставки (штрафів у } \\
\text { разі запізнення доставки товару). Як шлях подолання такої ситуації мо- } \\
\text { жливо запропонувати внесення даних до системи партіями, не чекаючи } \\
\text { закінчення всього виробництва (якщо це можливо за правилами вироб- } \\
\text { ництва). }\end{array}$ \\
\hline 2 & $\begin{array}{l}\text { Якість транспортного } \\
\text { обслуговування }\end{array}$ & $\begin{array}{l}\text { Якість транспортного обслуговування (як при власному транспорті, так і } \\
\text { при залученні зовнішніх транспортних компаній). Останнім часом виро- } \\
\text { бничі та торгові підприємства все частіше, приймають рішення про пе- } \\
\text { редачу всіх або частини перевезень на аутсорсинг. Це дозволяє сконцен- } \\
\text { труватися на основній сфері діяльності, та довірити транспортну логіс- } \\
\text { тику професіоналам у цій галузі, що в результаті повинно покращити } \\
\text { якість перевезень, а в багатьох випадках - і знижує транспортні витрати. }\end{array}$ \\
\hline 3 & $\begin{array}{l}\text { Невідповідні транспортні } \\
\text { засоби }\end{array}$ & $\begin{array}{l}\text { Невідповідні транспортні засоби - коли транспорт не відповідає заявле- } \\
\text { ним у транспортній заявці параметрам. В разі зносу транспортного засо- } \\
\text { бу - може виникнути конфліктна ситуація, наприклад: старенька ванта- } \\
\text { жна машина і зношена підлога - замовник може відмовитись заїжджати } \\
\text { навантажувачем для здійснення загрузки/вивантаження товару; або, у } \\
\text { тентованій машині пошкоджений (дірявий) тент і пішов дощ - що при- } \\
\text { вело до затікання води у середину авто і пошкодження товару. Зробити } \\
\text { більш простою процедуру вирішення такого роду конфліктної ситуації } \\
\text { можливо, ще до початку перевезення, а саме знов таки заздалегідь про- } \\
\text { думав деталі договору, окрім того для вантажів із високою вартістю ба- } \\
\text { жано наймати перевізників або експедиційні компанії що мають відпові- } \\
\text { дні страхові поліси. }\end{array}$ \\
\hline 4 & $\begin{array}{l}\text { Інформаційна підтримка } \\
\text { перевезень }\end{array}$ & $\begin{array}{l}\text { Погана інформаційна підтримка перевезень - якщо не проінформували } \\
\text { про всі істотні умови (може спостерігатися з двох сторін, замовника та } \\
\text { перевізника). }\end{array}$ \\
\hline 5 & $\begin{array}{l}\text { Складнощі та неузгодже- } \\
\text { ність у складанні маршру- } \\
\text { тів руху }\end{array}$ & $\begin{array}{l}\text { Складнощі та неузгодженість у складанні маршрутів руху (будь то між- } \\
\text { народні перевезення або дистрибуція по місту); врахування часу на дос- } \\
\text { тавку та на якість доставки (наприклад: іхати по гарній дорозі буває до- } \\
\text { вше при цьому зберігається якість товару, або якщо обрати коротший } \\
\text { шлях по поганій дорозі (що часто практикують водії для економії пали- } \\
\text { ва), то можливо отримати зіпсований товар (наприклад: товар фарба в } \\
\text { металевих банках, або напої у тетра-паку - може пом'ятися, розлитися). } \\
\text { Також, важливим є маршрут руху при міжнародних перевезеннях, бо } \\
\text { треба знати через які пункти пропуску буде проходити машина та через } \\
\text { які країни (наприклад, можливо деяким товарам заборонено перетинати } \\
\text { відповідні країни). Конфліктні ситуації, що виникають при міжнародних } \\
\text { перевезеннях можуть дуже дорого коштувати, тому рішенням є ство- } \\
\text { рення для менеджерів процедури обов'язкового узгодження маршруту. }\end{array}$ \\
\hline 6 & $\begin{array}{l}\text { Недовантаження або } \\
\text { перевантаження автомобі- } \\
\text { лів за вантажопідйомністю }\end{array}$ & $\begin{array}{l}\text { Недовантаження або перевантаження автомобілів за вантажопідйомніс- } \\
\text { тю - цей конфлікт з боку адміністрування, можна статися, наприклад, у } \\
\text { разі відсутності або недостовірності даних про вагу товару в обліковій } \\
\text { системі. У випадку недовантаження компанія втрачає зайві гроші на } \\
\text { транспортування, набагато гірша ситуація коли відбувається переванта- } \\
\text { ження, що у випадку виявлення на ваговому терміналі буде дуже дорого } \\
\text { коштувати компанії. Рішенням цього конфлікту буде описання процесу } \\
\text { та визначення відповідальних осіб щодо внесення облікових даних про } \\
\text { товар в систему. }\end{array}$ \\
\hline
\end{tabular}




\begin{tabular}{|c|c|c|}
\hline & & Продовження табл.1 \\
\hline $\begin{array}{l}\text { № } \\
\text { 3/ח }\end{array}$ & $\begin{array}{c}\text { Рамки / зміст } \\
\text { конфліктної ситуації }\end{array}$ & Стисла характеристика конфліктної ситуації та методи вирішення \\
\hline 7 & $\begin{array}{l}\text { Наявність при транспорт- } \\
\text { них перевезеннях } \\
\text { бою/псування товару }\end{array}$ & $\begin{array}{l}\text { Наявність при транспортних перевезеннях бою/псування товару, що мо- } \\
\text { же виникнути не тільки з вини перевізника, а і з вини відправника, на- } \\
\text { приклад, у разі неякісної упаковки, що не відповідає характеристикам } \\
\text { товару. Рішення: знов таки страхування вантажів та транспортних засо- } \\
\text { бів, деталізація видів браку, а також усвідомлення компанією необхідно- } \\
\text { сті роботи з покращення якості упаковки та пакування товару. }\end{array}$ \\
\hline 8 & $\begin{array}{l}\text { Складнощі адмініструван- } \\
\text { ня перевезень за участю } \\
\text { декількох видів транспорту }\end{array}$ & $\begin{array}{l}\text { Складнощі адміністрування перевезень за участю декількох видів транс- } \\
\text { порту (мультимодальні перевезення) - набагато складніше спрогнозува- } \\
\text { ти за термінами і по можливим ризикам. При взамодії різних видів тра- } \\
\text { нспорту завжди підвищуються терміни перевезення, це пов'язано з пере- } \\
\text { вантаженнями з одного виду транспорту на інший (що може супрово- } \\
\text { джуватися короткостроковим зберіганням вантажу на логістичних тер- } \\
\text { міналах або складах); незначне зниження сумарної вартості перевезення } \\
\text { комбінується зі збільшенням термінів доставки і підвищенням складнос- } \\
\text { ті організації і контролю такого перевезення. Конфлікти, які виникають } 3 \\
\text { боку інформаційного супроводу коштують набагато гостріше, ніж при } \\
\text { перевезеннях одним видом транспорту. }\end{array}$ \\
\hline 9 & Корупційні побоювання & $\begin{array}{l}\text { Відомою конфліктною ситуацією є корупційні побоювання, щодо зави- } \\
\text { щення вартості перевезення. Часто керівництво компаній має підозри } \\
\text { стосовно власних менеджерів. Проте, сучасні технології дозволяють } \\
\text { унеможливити такі ситуації. Існує вже достатня кількість тендерних } \\
\text { площадок, де перевізники виборюють право перевезення того чи іншого } \\
\text { вантажу. Таке адміністративне рішення дозволить зменшити вартість } \\
\text { перевезення, бачити аналітику та зняти підозри з власних менеджерів. }\end{array}$ \\
\hline
\end{tabular}

* Розроблено авторами за матеріалами $[9 ; 10]$

Але, не завжди зовнішні перевізники надають якісні послуги. Часто такі компанії не мають власного рухомого складу і працюють як посередники між замовником і перевізником, тобто є експедицією. Існує багато експедиторських компаній, кожна 3 яких працює за своїми стандартами, а іноді без них. Тому надважливим є обрання правильної відомої стабільної експедиторської компанії з гарною репутаці$є ю$ що має активи достатні для відшкодування збитків у разі виникнення необхідності. Окрім того, треба ретельно підходити до узгодження деталей при заключенні договорів, чим більше ситуацій буде прописано у договорі, тим швидшим буде процес відшкодування збитків.

Щодо інформаційної підтримки перевезень важливо звертати увагу на такі приклади:

- замовник найняв машину для перевезення металу та не вказав на необхідність верхнього завантаження, відповідно авто приїхало без можливості такого завантаження, що призвело до відмови від цього авто, а відповідно до штрафу; окрім того треба буде шукати іншу машину для завантаження, робити нові документи, що іноді може бути досить складним або щонайменше призведе до втрати часу, наприклад коли треба робити перепустки до порту;

несвоєчасне надання документів для процедури митного очищення товару, що гарантовано призведе до простою та штрафу;

відсутність необхідних документів на авто або водія, наприклад машини що доставляють товар до АТБ повинні мати санітарну обробку, а водії медичну книжку, відсутність яких призводить до відмо- ви від прийняття товару та величезних штрафних санкції на постачальника;

- $\quad$ втрата зв'язку з водієм та машиною (особливо при перебуванні в іншій державі або на прикордонному переході), і моніторингу вантажу протягом перевезення, і контролю стану транспортного засобу, його місцезнаходження. Це негативно позначається на адмініструванні процесу транспортування, особливо у випадках потреби в терміновій передачі або коригування інформації для водія.

Шляхами подолання таких ситуацій є узгодження конкретних вимог до перевезення у заявці. Працівники компанії повинні чітко усвідомлювати яку саме інформацію треба подавати у заявці для завантаження авто, так само треба оговорити регламент спілкування із водієм або менеджером експедиційної компанії для отриманні необхідної інформації щодо здійснення перевезення, що особливо актуально для міжнародних перевезень. У разі необхідності узгоджувати режим контролю авто за допомогою GPS. Також, варто зазначити, що багато ситуацій можливо передбачити заздалегідь, але нестача у перевізників та замовників інформації про програмні продукти, що дозволяють спростити та прискорити виконання операцій, які супроводжують перевізний процес або взагалі небажання його автоматизувати, що характерно для невеликих підприємств, призводить до конфліктів що складно вирішувати. Наприклад, економія на датчику вимірювання температури (терморегістраторі) у рефрижераторі може привести до неможливості довести дотримання температурного режиму в процесі транспортування, а відповідно перевізнику доведеть- 
ся компенсувати зіпсовану продукцію, навіть якщо товар був невідповідної температури ще при завантаженні. Рішенням є моніторинг ринку програмного забезпечення та автоматизація процесів, що дозволить автоматизувати передачу та аналітику даних всім учасникам які прямо чи опосередковано залучені у транспортний процес [10].
Проведений аналіз типових причин виникнення конфліктних ситуацій та конфліктів при адмініструванні транспортних перевезень у логістичних системах, дає можливість запропонувати модель управління конфліктними ситуаціями на підприємствах логістичного профілю (рис.3).

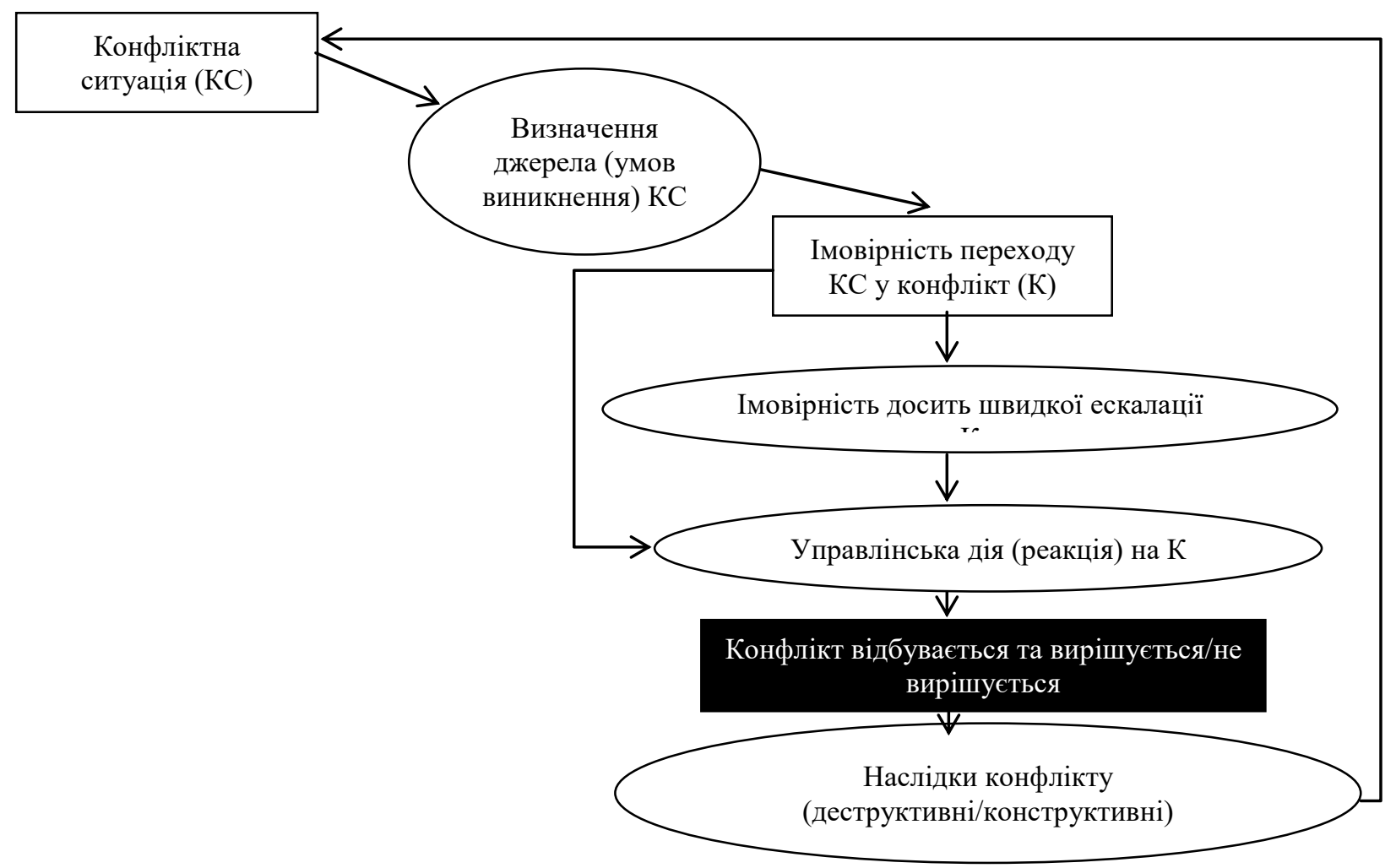

Рис.3. Модель управління конфліктними ситуаціями на підприємствах логістичного профілю* *розроблено авторами

Так, адміністрування транспортної логістики у логістичній системі на підприємстві здебільшого грунтується на базі проведення аналізу комунікаційних мереж та інформаційних потреб, а також управлінських реакцій. Найбільша увага повинна приділятися процесу прийняття рішення та визначенню подальших дій. Для розуміння прийняття рішень щодо подолання конфліктних ситуацій при адмініструванні транспортних перевезень у логістичних системах, слід досліджувати поведінку самої системи та їі компонентів, а також їх взаємодію між собою, знати підсистеми або основні області рішень; розуміти, як в дійсності приймаються рішення; розуміти спосіб, за допомогою якого області рішень зв'язуються комунікаційними каналами, що переносять інформаційні потоки [11, с.192].

Конфлікт описує ситуацію, коли дві або більше сторони мають незгоди та проявляють конфліктну поведінку. Вирішення конфлікту (тобто створення певних домовленостей) вимагає ресурсів i, отже, вимагає витрат конфліктуючих сторін. Крім того, відповідний процес може викликати відволікання уваги на управління співпрацею та відволікання уваги від питань, що мають більше значення або терміновість [12, с.387]. Це також негативно впливає на обробку інформації $[13$, с.9], і може погіршити довіру та прихильність [14, с.48] до підприємства, а отже негативно вплинути на економічні показники його діяльності .

Висновки та перспективи подальших досліджень. Виникнення конфліктних ситуацій та конфліктів при адмініструванні транспортних перевезень неминуче пов'язано з проблемами різного характеру, які виникають в процесі професійної діяльності будь якого підприємства. Частина науковців більш позитивно ставляться до виникнення конфлікту, оскільки вважають що виявлення і подолання конфліктної ситуації сприяє вдосконаленню процесів прийняття рішень [15, с.299]. Але, 3 практичної точки зору, зрозуміло, що виникнення конфліктів на будь-якому етапі діяльності підприємства, та у будь-якому підрозділі може призвести до втрати ресурсів (фінансових, трудових, тощо) та в цілому зруйнувати систему, в якій виник конфлікт.

Перш за все, слід відповісти на питання чи є конфліктна ситуація, як її вирішити та ухилитися від 
конфлікту, що було причиною, хто відповідальний, i що робити щоб уникнути подібного в подальшому, треба досліджувати усі причини виникнення конфліктних ситуацій на підприємстві та детально розуміти i розібрати на складові алгоритм реалізації кожної функції транспортних перевезень у логістичної системі, оскільки адміністрування транспортних перевезень у логістичної системи має велике значення для підприємства. Подолання конфліктних ситуацій та розв'язання конфліктів залежить від специфіки кожної конкретної ситуації, та повинно бути спрямоване у двох напрямках: робота на випередження потенційних конфліктів та оперативне вирішення вже виниклих. Але, одним з головних рішень щодо подолання конфліктних ситуацій розв'язання конфліктів буде розробка уніфікації типових дій (алгоритму) для менеджерів.

\section{Література}

1. Конфликты в логистический цепях неизбежны, поэтому их надо правильно воспринимать (результаты блиц-опроса экспертов) // Логистика: проблемы и решения. $2015 . \quad$ №2 (57) мартапрель. URL: https://www.lobanov-logist.ru/upload/iblock/5ff/5ff823c4a4328a68723b8a5dedf4b996.pdf (дата звернення: 03.10.20)

2. Родников А.Н. Логистика. Терминологический словарь. Москва : ИНФРА-М, 2000 . 340 с.

3. APICS Dictionary. 8 ht Edition. American Production and Inventory Control Society, Inc. 1995. P. 102

4. Трегубов В.И. Концепция синхронизации как основа администрирования в самоорганизующихся логистических системах // Вестник Саратовского государственного технического университета. 2010. Том 4, №2c. URL: https://cyberleninka.ru/article/n/kontseptsiya-sinhronizatsii-kak-osnova-administrirovaniya-vsamoorganizuyuschihsya-logisticheskih-sistemah/viewer (дата звернення: 01.10.20)

5. Лемеш I.O. Сутність логістичної системи та їі функціональна значущість на підприємстві в системі прийняття управлінських рішень // Управління розвитком. 2013. №1. 141с.

6. Сумець О. М. Логістика: теорії, ситуації, практичні завдання. Частина 1. Логістика як інструмент ринкової економіки. Київ.: "Хай-Тек Прес", 2010. 344c. 2005. 975 c.

7. Сергеев В.И. Корпоративная логистика: 300 ответов на вопросы профессионалов. М.: ИНФРА-М. 2015. 248c..

8. Король Л.Г., Малимонов И.В., Рахинский Д.В. Конфликтология. Ульяновск: Издательство «Зебра».

9. Левкин Г.Г. Контроллинг логистических систем: учебное пособие для вузов. М.: Юрайт. 2019. 167c.

10. Савченко Л.В. Проблемы транспортной логистики. Логистический интернет-портал: LobanovLogist.ru URL: https://www.lobanov-logist.ru/library/355/55586/ (дата звернення: 01.10.20)

11. Миротин Л.Б., Чубуков А.Б., Ташбаев И.Е. Логистическое администрирование. М.: Экзамен. 2003. 480c.

12. De Dreu, C.K.W. and Weingart, L.R. Task versus relationship conflict, team performance, and team member satisfaction: a meta-analysis // Journal of Applied Psychology. 2003. Vol. 88, № 4, P. 741-749. doi: 10.1037/00219010.88.4.741

13. Verstrepen S., Cools M., Cruijssen F. and Dullaert W. A dynamic framework for managing horizontal cooperation in logistics // International Journal of Logistics Systems and Management. 2009. Vol. 5, № 3/4, P. 228-248. . doi: 10.1504/IJLSM.2009.022497

14. Menon A., Bharadwaj S.G. and Howel R. The quality and effectiveness of marketing strategy: effects of functional and dysfunctional conflict in intraorganizational relationships // Journal of the Academy of Marketing Science. 1996. Vol. 24, № 4, P. 299-313. doi: 10.1177/0092070396244002

15. Hongzhuan Chen, Lulu Song, Xuesong Zhuang, Ting Li. Research on the Conflict Analysis of Supply Chain Management based on Graph Model with MRCR. 2nd International Conference on Software Engineering, Knowledge Engineering and Information Engineering. Published by Atlantis Press. 2014. URL: https://www.atlantispress.com/article/13605.pdf (дата звернення: 05.10.20) doi: 10.2991/sekeie-14.2014.13

16. Бауэрсокс Доналд Дж., Клосс Дейвид Дж. Логистика: интегрированная цепь поставок. Москва. ЗАО «Олимп-Бизнес». 2005. 640с.
Стаття надійшла 16.10.2020

Стаття прийнята до друку 30.10.2020 Доступно в мережі Internet 29.12.20 
Козак Е.Б.

кандидат экономических наук, доцент кафедра менеджмента и логистики E-mail: kozakkate.coach@gmail.com ORCID ID: 0000-0002-8099-6607
Дроздова В.А.

кандидат экономических наук, доцент кафедра менеджмента и логистики

E-mail: 78banka78@gmail.com

ORCID ID: 0000-0003-3143-1869

\author{
Дроздова Е.A. \\ магистрант \\ кафедра менеджмента и логистики \\ Одесская национальная академия пищевых технологий \\ ул. Канатная, 112, г. Одесса, Украина, 65039 \\ E-mail: e.drozdova@gmail.com \\ ORCID ID: 0000-0002-0743-2370
}

\title{
ПРЕОДОЛЕНИЕ КОНФЛИКТНЫХ СИТУАЦИЙ ПРИ АДМИНИСТРИРОВАНИИ ТРАНСПОРТНЫХ ПЕРЕВОЗОК В ЛОГИСТИЧЕСКИХ СИСТЕМАХ
}

\begin{abstract}
Целью статьи является проведение анализа причин конфрликтных ситуаций и конфрликтов, возникающих в связи со сложностями администрирования (управления) при транспортных перевозках, анализа мнений экспертов-практиков и ученых по преодолению подобных сложных ситуаций. Поскольку при управлении логистическими процессами у должностных лиц четко регламентированы функции, по которым они должны фокусироваться именно на процедурах и контроле за их выполнением, что иногда становится причинами возникновения конфрликтных ситуаций и конфлликтов. Задачей статьи является установление наиболее типичных причин конфликтных ситуаций в процессе администрирования транспортных перевозок; установление между какими участниками логистической системы наиболее часто возникают конфликтные ситуации; какие существуют пути и инструменты определения, сглаживания и решения подобных сложных ситуаций. Рассматриваются тенденции развития логистического менеджмента и логистики; понятие логистической системы, конфрликтной ситуации / конфлликта и администрирования. Анализируются мнения ведущих специалистов цепи поставок украинского рынка. Раскрываются причины межфункциональных и межорганизационных конфрликтных ситуаций связанных с администрированием транспортных перевозок. Предлагаются пути преодоления, которые могут повлиять на улучшение администрирования между отделами логистической системы внутри компании и с предприятиями-партнерами. Следует отметить, что конфликтные ситуации, возникающие в процессе транспортных перевозок, приводят к значительным экономическим и имиджевым убыткам для предприятия и компаний-партнеров, особенно при осуществлении международных перевозок, а также остаются без внимания ученых, хотя беспокоят представителей бизнес-структур. Поэтому именно проблема качественного администрирования транспортных перевозок в логистических системах и своевременное выявление и преодоление конфликтов с наименьшими затратами приобретает актуальность.
\end{abstract}

Ключевые слова: конфликтная ситуация, конфрликт, логистическая система, транспортные перевозки, логистическое администрирование, международная логістика.

Kozak K.

Ph.D., Associate Professor

Department of Management and Logistics

E-mail: kozakkate.coach@gmail.com ORCID ID: 0000-0002-8099-6607
Drozdova V.

Ph.D., Associate Professor

Department of Management and Logistics

E-mail: 78banka78@gmail.com

ORCID ID: 0000-0003-3143-1869

\section{Drozdova Y.}

Undergraduate

Department of Management and Logistics

Odessa National Academy of Food Technologies

Kanatna str., 112 Odesa, Ukraine, 65039

E-mail: e.drozdova@gmail.com

ORCID ID: 0000-0002-0743-2370

\section{OVERCOMING CONFLICT SITUATIONS IN THE ADMINISTRATION OF TRANSPORTATION IN LOGISTICS SYSTEMS}

The purpose of the article is to analyze the causes of conflict situations and conflicts arising in connection with the difficulties of administration (management) in transportation, analysis of opinions of practi- 
tioners and scientists on overcoming such difficult situations. Since, when managing logistic processes, managers have clearly regulated functions, according to which they should focus specifically on procedures and monitoring their implementation, which sometimes becomes the cause of conflict situations and conflicts. The aim of the article is to establish the most typical causes of conflict situations in the process of administration of transportation; finding out between which participants in the logistics system conflict situations arise most often; what are the ways and tools for determining, smoothing and solving such difficult situations. Trends in the development of logistics management and logistics are considered; the concept of a logistic system, conflict situations / conflict and administration are considered as well. The opinions of leading experts of the supply chain of the Ukrainian market are analyzed. The reasons for inter-functional and interorganizational conflict situations associated with the administration of transportation are revealed. The ways of overcoming that can affect the improvement of administration between departments of the logistics system within the company and with partner enterprises are proposed. It should be noted that conflict situations arising in the process of transportation lead to significant economic and image losses for the enterprise and partner companies, especially during international transportation and also remain unnoticed by scientists, although the representatives of business structures are considered about them. Therefore, it is the problem of high-quality administration of transportation in logistics systems and the timely identification and overcoming of conflicts at the lowest cost that becomes relevant.

Key words: conflict situation, conflict, logistics system, transportation, logistics administration, international logistics.

\section{References}

1. Konfliktyi v logisticheskiy tsepyah neizbezhnyi, poetomu ih nado pravilno vosprinimat (rezultatyi blits-oprosa ekspertov). (2015). Logistika: Problemyi i Resheniya, (2(57). Retrieved October 03, 2020, from https://www.lobanovlogist.ru/upload/iblock/5ff/5ff823c4a4328a68723b8a5dedf4b996.pdf

2. Rodnikov, A. N. (2000). Logistika. Terminologicheskiy slovar. Moscow: INFRA-M.

3. American Production and Inventory Control Society. (1995). Apics Dictionary (8th ed.).

4. Tregubov, V. I. (2010). Kontseptsiya sinhronizatsii kak osnova administrirovaniya v samoorganizuyuschihsya logisticheskih sistemah. Vestnik Saratovskogo gosudarstvennogo tehnicheskogo universiteta, 4(2). Retrieved October 01, 2020, from https://cyberleninka.ru/article/n/kontseptsiya-sinhronizatsii-kak-osnova-administrirovaniya-vsamoorganizuyuschihsya-logisticheskih-sistemah/viewer

5. Lemesh, I. O. (2013). Cutnist lohistychnoi systemy ta yii funktsionalna znachushchist na pidpryiemstvi v systemi pryiniattia upravlinskykh rishen. Upravlinnia rozvytkom, (1).

6. Sumets, O. M. (2010). Lohistyka: teorii, sytuatsii, praktychni zavdannia (Part 1. Lohistyka yak instrument rynkovoi ekonomiky). Kyiv: "Khai-Tek Pres".

7. Sergeev, V. I. (2005). Korporativnaya logistika: 300 otvetov na voprosyi professionalov. Moscow: INFRA-M.

8. Korol, L. G., Malimonov, I. V., \& Rahinskiy, D. V. (2015). Konfliktologiya. Ulyanovsk: Izdatelstvo «Zebra».

9. Levkin, G. G. (2019). Kontrolling logisticheskih sistem: uchebnoe posobie dlya vuzov. Moscow: Yurayt.

10. Savchenko, L. V. Problemyi transportnoy logistiki. Logisticheskiy internet-portal: Lobanov-Logist.ru. Retrieved October 01, 2020, from https://www.lobanov-logist.ru/library/355/55586/

11. Mirotin, L. B., Chubukov, A. B., \& Tashbaev, I. E. (2003). Logisticheskoe administrirovanie. Moscow: Ekzamen.

12. De Dreu, C. K. W., \& Weingart, L. R. (2003). Task versus relationship conflict, team performance, and team member satisfaction: a meta-analysis. Journal of Applied Psychology, 88(4), 741-749. doi: 10.1037/0021-9010.88.4.741

13. Verstrepen, S., Cools, M., Cruijssen, F., \& Dullaert, W. (2009). A dynamic framework for managing horizontal cooperation in logistics. International Journal of Logistics Systems and Management, 5(3/4), 228-248. doi: 10.1504/IJLSM.2009.022497

14. Menon, A., Bharadwaj, S. G., \& Howel, R. (1996). The quality and effectiveness of marketing strategy: effects of functional and dysfunctional conflict in intraorganizational relationships. Journal of the Academy of Marketing Science, 24(4), 299-313. doi: 10.1177/0092070396244002

15. Hongzhuan Chen, Lulu Song, Xuesong Zhuang, \& Ting Li. (2014). Research on the Conflict Analysis of Supply Chain Management based on Graph Model with MRCR. In 2nd International Conference on Software Engineering, Knowledge Engineering and Information Engineering. Atlantis Press. Retrieved October 05, 2020, from https://www.atlantis-press.com/article/13605.pdf doi: 10.2991/sekeie-14.2014.13

16. Bauersoks Donald Dzh., \& Kloss Deyvid Dzh. (2005). Logistika: integrirovannaya tsep postavok. Moscow: ZAO «Olimp-Biznes».

Received 16 October 2020

Approved 30 October 2020

Available in Internet 29.12.2020

Цитування згідно ДСТУ 8302:2015

Козак К.Б., Дроздова В.А., Дроздова Є.А. Подолання конфліктних ситуацій при адмініструванні транспортних перевезень у логістичних системах // Економіка харчової промисловості. 2020. Т.12, вип. 4. С.26-34. doi: 10.15673/fie.v12i4.1908

Cite as APA style citation

Kozak, K., Drozdova, V., \& Drozdova Y. (2020). Overcoming conflict situations in the administration of transportation in logistics systems Food Industry Economics, 12(4), 26-34. doi: 10.15673/fie.v12i4.1908 